\title{
THE INFLUENCE OF SUBTITLE FILM ON STUDENTS' LISTENING MOTIVATION
}

\author{
Nur Zahrah Azizah \\ Universitas Negeri Makassar \\ Zahrah.azizah03@gmail.com \\ Muhammad Yaumi \\ Universitas Islam Negeri Alauddin Makassar \\ muhammad.yaumi@uin-alauddin.ac.id
}

\begin{abstract}
This paper is aimed to describe the influence of making subtitle film on students' listening motivation. The population of this research is the second semester students of English Education Department in academic year 2016/2017. The method used in this paper was a quantitative method with experimental research design. In addition, the research data were collected by using questionnaire. The data were analyzed through Likert scale and descriptive statistics. The result research shows that the mean score of students' pre-questionnaire is 60.9 from the total score 1462 and the post questionnaire is 65.8 from the total score 1580. The result of analysis indicates that in teaching listening by making subtitle film can increase their listening motivation. It proved by $\mathrm{t}$-test which is higher than $\mathrm{t}$-table.. It also means that there are a significant influence of the use subtitle film in increasing students' motivation in listening.
\end{abstract}

Keywords: Making subtitle film, students' motivation, students' listening

\section{A. INTRODUCTION}

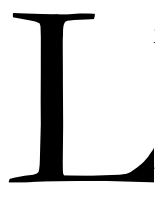

istening is the activity of paying attention to and trying to get meaning from something we hear. In order to listen to spoken language, we are required to understand what do the speakers mean when they use particular words in particular ways on particular occasions, and not simply understand the words themselves. Therefore, students have to not only pay attention to the sound but also the situational context and the gesture.

Guiding students to improve their listening ability is quite difficult, because listening is very individual activity. Individual activity means that only the listener in this case, are students understand what they hear because the process is on the students mind. Therefore, listening in learning English exactly needs a lot of things including the teachers' learning strategies in the class, learning methodologies, students' willingness to study, and so on.

According to researcher's preliminary research, the researcher occasionally finds problems including: the students only learn listening on the campus and not continue at their home (lack of practicing) and students' lack motivation to learn listening because their perception about listening is difficult. They need more repeating, they were limited by the 
time, it is because of the time provided by the school was really short. That is why we need to offer an activity to the student and led them practice not only at school but also at home as well as other places. If it is not overcome soon, the researchers worry it is difficult for student to improve their motivation and their listening comprehension significantly.

Therefore, the researcher tried to give an alternative strategy of teaching listening through making Film Subtitle. Subtitle Film is the printed translation over a film either in a foreign or the same languages to explain the actors' statement. By making subtitle film, students' concentration in following words can be enhanced and also can develop students' word recognition skill because listening to the original dialogues.

Based on the reasons above, the researcher wants to conduct an experimental research in teaching listening by making subtitle film in order to motivate the students of Academic Year 2016/2017 in English Education Department.

\section{B. LITERATURE REVIEW}

\section{Previous Related findings}

Many research about Listening that researcher found that related to this research but not similar with this research. For examples, Ramadhika (2014) found that the use of animation videos in English teaching and learning process can improve the students' listening skills and the teacher's performance. There was an increasing mean score of the students from 7.2 in the pre-test to 8.2 in the post-test. There were some good improvements in some aspects such as their familiarity in listening to English words and their vocabulary.

Nurpahmi (2015) found that the students ability in listening can be improved by activating students' prior knowledge. The research conducted at English education study program of faculty of Tarbiyah and education of UIN Alauddin Makassar. This research applied cluster random sampling method. The research data were collected using listening test. It was given at pretest and posttest to know the students' achievement on listening. The difference of this research and Nurpahmi research, Nurpahmi look for the Listening skill improvement but the researcher look for the specific one that is students motivation.

Research conducted by Latifi, Mobalegh and Mohammad (2011) revealed that regarding immediate comprehension, both subtitles groups outperformed the NSG; however, on the IELTS test which measured the long term improvement of the learners the No subtitles group performed significantly better. Despite the immense support for using 
captions and subtitles, some scathing criticisms have been leveled against their efficacy in improving actual listening comprehension ability.

Talavan (2005) found that making subtitling technique to the students can improve the four skill of the students. He concludes that this subtitling technique can be used as the basis of a project activity, where complete short films, a chapter from a TV sitcom, or a short documentary feature film can be subtitled once or twice a year, so that students feel that they are fulfilling a real and complete task; although this type of project take several sessions and outside class time, students feel the extra motivational factor of achieving a real outcome with total completion and achievement.

Ghorbani in his research entitled "Waching Cartoons with Subtitle Improves Children's Foreign Language Acquisition" found that his participant, Morteza, get improvement by watching cartoon with or without subtitle. The participant was an Iranian 12-year-old boy, Morteza, who watched more than 20 cartoon enhanced with English subtitles in two years. After mastering each cartoon, he took the direct listening, pronunciation, vocabulary and comprehension test orally. The testing sessions were followed by an oral interview regarding the usefulness of subtitles. The results indicated that his performance increamentally improved. Ghorbani research only used one person as the sample of his research while the researcher used one class as the sample. So we can say that Ghorbani and the researcher research is different.

Research on motivation we can find from Zululaefah Burhan (2017)found that students' motivation can be increased by variant technic of ice breaker. She state that there was significant difference on the students' motivation taught by using ice breaker. The students' mean score of the pre-test of the experiment class was 60 . Then, in the post-test, the mean score of experiment class was 66.1. It could be said that ice breaker was effective in teaching English learning toward students' motivation for the first grade of junior high school students.

\section{Motivation in Listening}

Douglas Brown (2007) delineates motivation is the anticipation of reward internally or externally administered, choices made about goals to gain and the effort exerted in their completion Deborah Sardo-Brown, dkk (2003) explain that the motivation is happened when a person is energized to satisfy some need or desire. The person will engaged in, or be attracted toward, activities that are perceive that having the potential to meet this need and desire (Deborah Sardo-Brown, dkk., 2003: 276). 
Harmer (1991) categorized motivation into intrinsic motivation and extrinsic motivation. Robert N. Singer (1975)a defines intrinsic motivation is the origin of a drive within a person, or it can be analyzed as something is done for its own sake (Robert N. Singer, 1975:403). Deborah Sardo-Brown (2003) stated that extrinsic motivation is operative when an individual is motivated by an outcome that is external or somehow related to the activity in which she or he engaged (Deborah Sardo-Brown, 2003: 279). In another words it can be concluded that intrinsic motivation comes a person internally and extrinsic motivation is the motives that are aroused from outside.

Motivation in listening is students' internal or external drive that encourages or empower them to participate in listening class. Internal drive of the students can be empowered by facilitating students with the interesting activity.

\section{RESEACH METHOD}

The design of this research was pre-experimental design, exactly One Group Pretest posttest Design that involving one class as an experimental group. This group get a treatment by making subtitle film. Before giving treatment, this group would be given a pre-study questionnaire to find out their prior motivation. After given the treatment, this group would be given a post-study questionnaire to find out their motivation on listening class by making subtitle film.

To calculate the result of pre and post-questionnaire, researcher applied Likert scale. In this scale, each respondent was asked individually to respond a series of statements by indicating whether or not he or she is strongly agree (SA), agree (A), undecided $(\mathrm{U})$, disagree (D), or strongly disagree (SD) about the statements given. Each response has its own value.

Table 1. Questionnaire scale

\begin{tabular}{|r|c|c|c|}
\hline \multirow{2}{*}{ NO } & \multirow{2}{*}{$\begin{array}{c}\text { SERIES OF } \\
\text { STATEMENT }\end{array}$} & POSITIVE & NEGATIVE \\
\cline { 3 - 4 } & & 5 & 1 \\
\hline 1 & Strongly Agree & 4 & 2 \\
\hline 2 & Agree & 3 & 3 \\
\hline 3 & Undecided & 2 & 4 \\
\hline 4 & Disagree & 1 & 5 \\
\hline 5 & Strongly Disagree & & \\
\hline
\end{tabular}


Nur Zahrah Azizah, Muhammad Yaumi, The Influence Of Subtitle...

The population of this research took from the students in Academic Year 2016/2017 of English Education Department in UIN Alauddin Makassar. The total numbers of the population were 107 students, consists of 3 classes. The technique sampling used in this research was purposive sampling. The researcher took a class as the sample to get representative data. The researcher took one class as the experimental class. The researcher took PBI 1.2 consist of 24 students as the sample.

Data of the research was analyzed by using descriptive and inferential statistics.

\section{FINDINGS AND DISCUSSION}

Based on the data analysis of pre-questionnaire, it was found that the mean score of students' motivation was 60.9. It was categorized as motivated. It means that the students' motivation in learning listening skill of English Education students in academic year 2016/2017 using conventional methods or media used by the teachers was motivated. These data can be seen in the following table.

Table 2. Students' Level of Motivation before treatment

\begin{tabular}{clccc} 
No & \multicolumn{1}{c}{ Category } & Range of Score & Frequency & Percentage \\
1 & Strongly motivated & $67-80$ & 3 & $13 \%$ \\
2 & Motivated & $54-66$ & 18 & $75 \%$ \\
3 & Fairly motivated & $42-53$ & 2 & $8 \%$ \\
4 & Unmotivated & $30-41$ & 1 & $4 \%$ \\
5 & Strongly unmotivated & $16-29$ & - & - \\
& $\quad$ Total & & 24 & $100 \%$
\end{tabular}

The process of students learning by teacher before treatment was good, we can see from the data above that shows only one student (4\%) that feel unmotivated and two students $(8 \%)$ in fairly motivated when learning listening. Besides, the data shows that 18 students or $75 \%$ was motivated and 3 students or $13 \%$ in strongly motivated condition.

Based on the data analysis of Post questionnaire, I found that the mean score of students' motivation was 65.83. It was in motivated category. It means that the students' motivation in learning listening skill of English Education students in academic year 
Volume 4, Number 01, June 2018

2016/2017 with making subtitle film strategy was motivated. These data can be seen in the following table.

Table 3. Students' Level of Motivation after treatment

\begin{tabular}{ccccc} 
No & Category & Range of Score & Frequency & Percentage \\
1 & Strongly motivated & $67-80$ & 11 & $46 \%$ \\
2 & Motivated & $54-66$ & 13 & $54 \%$ \\
3 & Fairly motivated & $42-53$ & - & - \\
4 & Unmotivated & $30-41$ & - & - \\
5 & Strongly unmotivated & $16-29$ & - & - \\
\multicolumn{2}{c}{ Total } & & 40 & 100
\end{tabular}

The data in the table above indicate that learning process by making subtitle film really good to improve students' motivation; we can see from the data that there is no student feel unmotivated, fairly motivated, or strongly unmotivated. They all were in motivated and strongly motivated condition. Eleven students or $46 \%$ whose scores were in the strongly motivated category, and thirteen students or $54 \%$ whose scores were in the motivated category.

After classifying the students' motivation, the next are the mean score and the standard deviation of the pre-test and the post-test that can be showed in the following table:

Table 4. Means score of the questionnaire score

\begin{tabular}{|c|c|c|c|c|}
\hline \multirow{2}{*}{ Class } & \multicolumn{2}{|c|}{ Pre-questionare } & \multicolumn{2}{c|}{ Post-questionare } \\
\cline { 2 - 5 } Experimental & Mean & Standard & Mean & Standard \\
& Score & Deviation & Score & Deviation \\
\cline { 2 - 5 } & 60,9 & 7,6 & 65,8 & 5,05 \\
\hline
\end{tabular}


In order to know whether or not the mean score was statically different from two variables (pre-test and post-test) at the level of significant difference $(0,05)$ with 47 degree of freedom $(\mathrm{df})=\mathrm{N}-1$, where $\mathrm{N}=$ the total of the students (24). The following table shows the result of the $\mathrm{t}$-test and $\mathrm{t}$-table calculation:

Table 5. T-test

\begin{tabular}{|c|c|c|}
\hline Variable & t-test & t-table \\
\hline $\mathrm{X}_{1}-\mathrm{X}_{2}$ & 2.482 & 2.07 \\
\hline
\end{tabular}

The table above indicates that the value of the t-test was higher than the value of the $\mathrm{t}$ table. It indicates that there was a significant difference between the result of the students' pre-test and post-test.

The result of data analysis showed that making subtitle film has managed to increase the students' motivation in Listening class; it could be seen from the effectiveness of making subtitle film strategy from the t-table above. It shows that the t-test value was higher than $\mathrm{t}$ table value. The t-test got 2.482 and t-table got 2.07. It meant that there was significant improvement after treatment, so the students' motivation in English learning was effective by making subtitle film. In general, the performance of the students improved by making subtitle film, most of them were in motivated and strongly motivated category. The use of making subtitle film in learning listening was effective. Some statements from the previous researcher supported this study, Motivation in activators which make someone to do and like something.

The data showed that most of the students liked to join the listening class by making subtitle film. It is relevant to the findings of Latifi, M., Mobalegh, A. and Mohammadi, M (2011) who investigated that watching film concise introduction provides a broad, complete, and yet specific picture of visual narrative techniques that will increase listener's excitement about and knowledge of the possibilities of the film medium.

The data also showed that most of the students had high motivation in learning to listen the dialogue by making films because they were very interested in the new media of learning. The teacher give the students task to listen the film and make the subtitle in pair. It is in line with Richards' theory (1983). He explained that that group activities are necessary in the classroom. Teachers have important roles to organize the classroom as a setting for communicative activities, monitor, encourage, and suppress the inclination to supply gaps in lexis, grammar, and strategy but note such gaps for later commentary and communicative 
practice. It means that through group activity the students learn to interact verbally and nonverbally, cooperate with each other to accomplish the goal, and respect to one another. Harmer (1991) states that pair work seems to be a good idea in learning process because it immediately increases the amount of students practice. It allows the students to use language and also encourages students' co-operation which is itself important for the atmosphere of the class and for the motivation.

From the discussion above, it was concluded that making subtitle film motivates second grade students in Academic year 2016/2017. All of the indicators of motivation stated in post-study questionnaire were high, so it means that the use of making subtitle film is able to engage the motivation of the students in learning the listening skill.

\section{E. CONCLUSION}

Based on findings and discussion it indicates that teaching listening by making subtitle film is effective to make students increase their listening motivation as well as their listening skill. It proved by the result of the research that shows that the mean score of students' pre questionnaire is 60.9 from the total score 1462 and the post questionnaire is 65.8 from the total score 1580 . The result of analysis of t-test is 2.482 . This value shows that there is significant difference because the $\mathrm{t}$-obtained is higher than $\mathrm{t}$-table, $2.482>2.07$. It means there is significant influence to the treatment that was given. Based on the findings, it is advisable that the English teachers should apply or implement making subtitle film in their listening classes .because it can improve the students' motivation.

\section{REFFERENCES}

Abdullah, U., \& Rahman, I. F. (2017). The Correlation Between Students'habit In Watching Movie And Listening Skill. ETERNAL (English, Teaching, Learning, and Research Journal), 3(1), 97-106.

Arikunto, Suharsimi. (20130. Prosedur Penelitian Suatu Pendekatan Praktik. Jakarta: PT. Rineka Cipta,

Baker, Mona.(2001). Routledge Encyclopedia of Translation Studies. New York: Routledge.

Brown, H. Douglas. (2001) Principles of Language Learning and Teaching. Englewood Cliffs, New Jersely: Prentice Hall Regents. 1994. Teaching by Principle An Integrate Approach to Language Pedagigy. Second Edition. Englewood Cliffs, New Jersely: Prentice Hall Regents. 
Budiman, W. (2013). Pengaruh Penggunaan Film Dokumenter Terhadap Hasil Belajar Siswa. The Internet On Line (http://Repository .upiedu/498/ktp0900919-CH/KR.Pdf. Downloaded on January 12, 2017.

Burhan, Zululaefah. (2017) Improving Students' Motivation using Ice breaker in English Learning at the First Grade of MTs Madani Alauddin Pao-pao. Unpublish thesis. Makassar: UIN Alauddin Makassar.

Depdikbud. (1985). Petunjuk Pelaksanaan Proses Belajar Mengajar dan Petunjuk Pelaksanaan Penilaian. Jakarta : Departemen Pendidikan dan Kebudayaan.

Djamarah, S.B. (2008). PsikologiBelajar. Jakarta: PT Rineka Cipta.

Gay, L. R. (2006). Education research: Competences For Analysis and Aflication. Columbus. Onion: Charles E Mevil Publishing Company.

Ghorbani, Mohammad Reza. (2011). Waching Cartoons with Subtitle Improves Children's Foreign Language Acquisition. Bojnord University: Iran. 2011.

Gonzales-Moncada, (2003). A. On materials use training in EFL teacher education: some reflections. Retrieved January 29, 2017 from Harmer, J. Teaching with Video. Birmingham: Editorial Longman, 2001http:/ / www.scielo.org.co/scielo.php?script=sci_arttext\&pid=S165707902006000100008\&lng $=$ en\&nrm $=$ iso

Harmer, J. (1991). The Practice of English Language Teaching.New York: Longman Inc.1991.

Karim. (2007). Encouraging Students to Speak English through Problem Solving Technique. Unpublished Thesis. Makassar: PPs UNM. 2007.

Latifi, M., Mobalegh, A. and Mohammadi, M. (2011). Movie Subtitles and the Improvement of Listening Comprehension Ability: Does it help?, in Journal of Language Teaching and Learning, 1, 2: 18-29. 2011

. (2014). The Effect of Using Movie Scripts as an Alternative to Subtitles: How to Improve Listening Comprehension. In Porta Linguarum Journal, 22. 203-217

Nurpahmi, s., \& thamrin, a. M. (2016). The influence of taking a part time job towards students'learning motivation at the seventh semester students of english education department of uin alauddin makassar. Eternal (english, teaching, learning, and research journal), 2(1), 63-81.

Nurpahmi, S. (2015). Improving listening skill by activating students'prior knowledge. ETERNAL (English, Teaching, Learning, and Research Journal), 1(1), 28-38. 
Ramadhika, Boris. (2014). Improving Students' Listening Skills Using Animation Videos for The Eighth Grade Students of SMPN 6 Magelang in The Academic Year of 2013/2014. A Thesis of Yogyakarta State University.

Rasyid, Abd. (2007). The Effectiveness of Language Games in Teaching Speaking Class to the Eight Grade Students of SMP Negeri 1 Maros. Unpublished Thesis. Makassar: PPs UNM. 2007

Richards, J. C. (1983). Listening comprehension: Approach, design, procedure. TESOL Quarterly, 17.219-239. 1983

Samsibar, (2017). The Effectiveness of Role Play Method towards the First Grade Students' Motivation in English Conversation at MTs No. 49 Bola Aserae -Belawa. Unpublish thesis. Makassar: UIN Alauddin Makassar.

Steinberg, Sheila. (2007). An Introduction to Communication Studies. Juta and Company Ltd.

Stewart, David M. (2006). Film English: Using Films to Teach English. National Central University, Taiwan. Electronic Journal of English Education 24. 2006) downloaded on January 27, 2017.

Suanti.. (2009). Pengaruh Persepsi Siswa Tentang Kompetensi Profesional Guru Terhadap Prestasi Belajar.

Sugiyono. (2015). Metode Penelitian Pendidikan: Pendekatan Kuantitatif, Kualitatif, dan R\&D. Edition XXII; Bandung: Alfabeta.

Talavan, Noa. (2005). Using Subtitles to Enhance Foreign Language Learning. In Porta Linguarum Journal. 6. 41-52.

Underwood, Mary. (1989). Teaching Listening. New York: Longman Inc, 1989.

Van Duzer, C. (1997). Improving ESL Learners' Listening Skills: At the workplace and beyond. 1997. Retrieved January 29, 2017, from http://www.cal.org/caela/esl_resources/digests/LISTENQA.html

Kline, John.(1996). Effective Listening. Air University Press. 